\title{
Deformation Fabric and Vein Emplacement in the Rocks of Gadag-Chitraudrga Schist Belt (Western Dharwar craton, Southern India) - Relationship with Regional Tectonics - Tridib Kumar Mondal, Department of Geological Sciences, Jadavpur University, Kolkata - 700 032. E-mail: tridibkumarmon dal@gmail.com
}

Abstract of Lecture delivered on $9^{\text {th }}$ January, 2019 at the Montly Meeting of the Geological Society of India, Bangalore

The upper crustal fluid flows are governed by the pre-existing anisotropy (fractures/foliations) in the rocks under a certain state of tectonic stress and fluid pressure condition. The studies on such aspect are important to decipher the mechanism of hydrothermal fluid flow that led to the vein emplacement and deposition of the economic mineral in a region. The present study involves the analysis of the deformation fabric and its control on vein emplacement in the rocks of Gadag-Chitraudrga Schist Belt (Western Dharwar craton, Southern India). The Gadag-Chitradurga Schist belt is a NNW-SSE trending, Archaean greenstone belt, replete with widespread network of veins with potential gold bearing lodes. The present study focuses on quantifying the fabric of visually isotropic rocks (such as metabasalts, granite), evaluate the process of vein emplacement in the host rocks of the region (metapelites/meta-argillites) and establish a timerelationship between vein emplacement and fabric development in the rocks.

The study involves an integration of field, anisotropy of magnetic susceptibility (AMS), and microstructural studies. The internal fabric of the rocks of the region is recorded from AMS studies. The magnetic foliation is dominantly NW-SE oriented, which is parallel to regional trend of the schist belt. The magnetic lineations are doubly plunging - due NW and SE. It is concluded that the magnetic foliation in the rocks of Chitradurga region developed during D1/D2, on account of NE-SW directed shortening and the doubly plunging attitude of the magnetic lineation indicates superimposition of D3 deformation.

The state of stress condition are obtained from the 3-D Mohr circle, prepared from the vein orientation data. The study reveals that the fracture/vein are the combined effect of regional stress field (far field stress), stress ratio (F) and the prevailing fluid pressure condition; such that the fluid pressure builds and exceeds the stresses acting on the fracture wall enabling dilation of the fracture planes, a mechanism known as fault-valve action. Subsequently, fluid flows into the fractures, a phenomenon analogous to burping, led to the formation of veins in various orientations and triggering a drop in the fluid pressure. Thus, repeated cycles of elevated and depleted fluid pressure generates vein network in the region. The paleostress analysis from the normal faults and fractures yields NW-SE to E-W directed shortening (paleostress) during D3 deformation, produced several brittle structures in the region which enhances the fracture network and leads to increase of permeability. This governs the pathway of hydrothermal fluid flow that subsequently led to vein emplacement in the region. 